\title{
International Journal of Food Research
}

\author{
www.bluepenjournals.org/ijfr
}

\section{Quality attributes of pro-vitamin A cassava-African yam bean noodles using response surface methodology}

\author{
Ajibola, Ghaniyah O.* and Olapade, Abiodun A. \\ Department of Food Technology, Faculty of Technology, University of Ibadan, Ibadan-200284, Nigeria.
}

\begin{abstract}
Article History
Received 07 December, 2020

Received in revised form 11

February, 2021

Accepted 22 February, 2021

Keywords:

Cassava noodles,

Indigenous crops,

Optimization,

Processing

parameters,

Protein enrichment.

Article Type:

Full Length Research Article

ABSTRACT

Noodles are globally recognised wheat-based food due to its universal acceptability. There is massive dependence on imported wheat for fast foods in non-wheat producing nations like Nigeria. Indigenous crops like pro-vitamin A cassava (PVAC) and African yam bean (AYB) could replace wheat in noodle production. Utilization of PVAC and AYB flour blend for preparation of noodles is sparse. This study was designed to optimize the quality attributes of noodles prepared from PVAC and AYB flour blend. The chemical composition of the blend was investigated using standard methods. The noodles were prepared from desirable blend and optimized using response surface methodology (RSM) to investigate the impact of processing parameters on noodle quality. Experimental data were sufficiently fitted into polynomial models with both high coefficient of determination $\left(R^{2}\right)$ and adjusted $\mathbf{R}^{2}$, and non-significant lack of fits. Thus, an optimum condition of a noodle with a hydration level of $50 \%$ and a steaming time of $1 \mathrm{~min}(50: 1)$ was achieved.
\end{abstract}

(C2021 Blue Pen Journals Ltd. All rights reserved

\section{INTRODUCTION}

Protein-energy malnourishment is a grave health problem worldwide, particularly in the emergent nations, including Nigeria. Around 14 million individuals of the entire Nigeria population are undernourished (FAO, 2012). This is because most diets eaten in numerous African nations contained low protein, mineral and vitamin-lacking starchy foods (Dickson et al., 2012). Noodles and new varieties of pasta are good energy-giving foods but poor in protein content (Eyidemir and Hayta, 2009). Africa requests for noodles have been increasing with rise in population (WINA, 2016). Based on WINA (2011), from 2007 to 2010; Nigeria was among the highest five quickest-growing countries in instant noodle consumption. It has thus become the largest instant noodle market in Africa. According to Jayasena et al. (2008), high rate of noodle consumption has ranked the noodle-associated company

\footnotetext{
${ }^{\star}$ Corresponding author. E-mail: ajibolaghaniyah@yahoo.com. Tel: $+234-8056348979$.
}

into second leading after bread. However, instant noodles are being regarded as 'junk food' because of their richness in carbohydrate but poor in protein, minerals, and vitamins (Choy, 2011).

By and large, noodles are prepared mainly from wheat flour, water, and other additives. Meanwhile, Nigeria cultivates essential crops apart from wheat such as cassava, yam, sweet potatoes, and cereals which could be utilized for bakery and convenience foods such as noodles. Hence, it would be economically beneficial if imported wheat could be substituted partly or completely with indigenously grown crops such as cassava in production of wheat-based foods (Oluwamukomi et al., 2011). The use of composite flour for noodle production has been documented with and without wheat incorporation (Ohimain, 2014). According to Abidin et al. (2013), cassava flour has a high possibility of replacing imported wheat flour which is broadly utilized to produce noodles. More than 800 million people depend on cassava as their main basis of calories (Sowmyapriya et al., 2017). Nigeria is presently producing around 59 million metric 
tonnes (MT) annually which is the leading global production (FAO, 2017). Cassava is deficient in protein content. Hence, fortification of pro-vitamin A cassava flour (CF) (Manihot esculenta Crantz), rich in vitamin A with legume is highly essential to enhance its nutritional quality; add value to its utilization in food formulation and thereby reducing the protein malnutrition problem of the consumers (Zvinavashe et al., 2011).

Legumes are the richest sources of protein, starch, minerals, and vitamins (Ahmed and Hasan, 2014). Many indigenous African food crops that have the potential of minimizing nutritional food insecurities are currently abandoned thus, underexploited (Ajayi, 2011). African yam bean (AYB) (Sphenostylis stenocarpa) is among those crops with tremendous nutritional potentials (Adewale and Odoh, 2013). Hence, the specific aim of this study was to evaluate the quality attributes of pro-vitamin A cassava-African yam bean noodles using RSM.

\section{MATERIALS AND METHODS}

\section{Materials}

M. esculenta Crantz of cultivar (070593) and $S$. stenocarpa Harms seeds of accession (TSs 94) were collected from Cassava Processing Unit and Genetic Resources Centre (GRC) of International Institute of Tropical Agriculture (IITA) Ibadan.

\section{Flours preparation}

Pro-vitamin A cassava roots of 10-12 months after planting were harvested, sorted, and processed into flours within $24 \mathrm{~h}$ of harvesting based on the description of Aniedu and Omodamiro (2012) with slight modification. The modification involves drying of pulverised cassava wet cake with the use of Niji Lukas flash dryer at $130^{\circ} \mathrm{C}$ for $20 \mathrm{~s}$ residence time instead of sun-drying on a raised platform. African yam bean seeds were processed into flour followed the technique described by Nwosu et al. (2011) with slight amendment. The amendment involved boiling duration of soaked seeds for $10 \mathrm{~min}$ instead of $30 \mathrm{~min}$.

\section{Experimental design}

Response surface methodology was employed for achieving required flour mixture for the preparation of cassava-African yam bean noodles applying Design Expert (version 6.0.6). According to Ajibola and Olapade (2019), two major ingredients were selected as independent variables: $\mathrm{CF}$ and African yam bean flour (AYBF) with values ranged from $60-90 \%$ and $10-40 \%$, respectively. These ranges were chosen based on the preliminary study on noodle preparation. The combination obtained from the design were quantified and thoroughly blended with the use of Bajaj grinder mixer (model GX 10 DLX, Bajaj Electrical Limited Mumbai, India) for $1 \mathrm{~min}$ to obtain similar mixtures. The dominant point of this design was replicated for five times to estimate the process reproducibility. Chosen criteria (responses) were to maximise the protein and $\beta$-carotene contents, while minimizing the fat content of the blend.

\section{Chemical composition of the blend}

The protein and fat contents of the blend were analyzed according to the description of AOAC (2005) method 978.04 and AACC (2000a) method 30-25, respectively.

\section{Beta carotene determination}

The procedure of Carvalho et al. (2012) was followed with minor amendment to extract and determine the beta carotene contents of flour blend. The amendment includes the use of different sample weight and solvent volume. From flour blend, $10 \mathrm{~g}$ was weighed into mortar, purified water was poured into it to soak the flour blend for $5 \mathrm{~min}$. Thirty millimetres of acetone was poured into it. This was allowed to stand for twenty minutes and $3 \mathrm{~g}$ of celite was added into the sample to aid the extraction. Pestle was used to crush the sample thrice for about 5 min each time and acetone was added to it at each crushing time until it was fully extracted. This was filtered with the use of suction via a Buchner funnel containing filter paper connected to the pump to aid the filtration.

The aliquot was conveyed to $500 \mathrm{ml}$ separation chimney holding forty millimetres of petroleum ether. The container was rinsed with acetone to ensure the removal of all the extract. The acetone was removed by careful washing via gentle addition of distilled water into the extract. The process was recurring for four times till no residual solvent left. The lower portion, being water was removed and upper part was cautiously transferred via little funnel holding cotton wool and anhydrous sodium sulphate for discarding residual water. This was added to $25 \mathrm{ml}$ mark with petroleum ether and permitted to settle.

Fifteen millimetres of the extract was transferred into concentrator container and concentrated at $40^{\circ} \mathrm{C}$ for 25 min in TurboVap $\AA$ LV concentration workstation (Caliper Life Sciences, U.S.A.). The concentrated extract was thinned with one millimetre of dichloroethane and one millimetre of methanol. This was stirred with vortex mixer and conveyed to a $2 \mathrm{ml}$ amber flask of high performance liquid chromatography (HPLC) apparatus (Agilent 1200 series, Perkin Elmer, USA). The instrument was turned on and produced corresponding chromatograph of each sample. The value obtained from the chromatograph was input into the equation to obtain the $\beta$-carotene. 
$\mathrm{C}=\frac{\mathrm{A}_{\mathrm{X}} \times \mathrm{C}_{\mathrm{S}}\left(\frac{\mu \mathrm{g}}{\mathrm{ml}}\right) \times \mathrm{V}(\mathrm{ml})}{\mathrm{A}_{\mathrm{S}} \times \mathrm{S}}$

Let $\mathrm{A}_{\mathrm{x}}=$ highest area of carotenoid, $\mathrm{C}_{s}=$ normal concentration, $A_{s}=$ normal area, $V=$ entire capacity of extract and $S=$ weight of sample in gram.

\section{Determination of numerical optimization of blend}

The independent and dependent variables were analyzed statistically using design expert (version 6.0.6) (Stat-Ease Inc. Minneapolis) to attain best blend. The numerical optimization of flour blend was investigated via the software and validated in the laboratory.

\section{Preparation of noodles from flour blend}

The optimum blend of CF and AYBF was used to prepare the noodles using the two processing parameters: steaming time and hydration level that varied from 1 to 3 min and 50 to $56 \%$, respectively as variables to obtain the required combinations from the design. A central composite design was utilized to examine the impact of selected processing parameters on noodle quality attributes during production. The chosen criteria were to minimize the hydrogen cyanide, cooking loss, stickiness, and chewiness, while maximizing the cooking yield and yellowness. The obtained combinations were used to prepare the noodles using the technique of Nwabueze and Anoruoh (2009) with some modifications. The modifications include the introduction of different steaming method and the use of SIMAC Pastamatic cold extruder. The water quantity requirement to form homogenous dough and attaining the established hydration level was obtained by adopting Akinoso et al. (2006) technique. The approaches of Oladunmoye et al. (2014) and Widjaya (2010) were adopted to obtain the quantity of other ingredients to be added to form the dough. For instance, to $100 \mathrm{~g}$ of flour blend, $0.1 \mathrm{~g}$ of sodium and potassium carbonates, $0.5 \mathrm{~g}$ of ascorbic acid and xanthan gum and $1.5 \mathrm{~g}$ of iodised salt were weighed and mixed with quantified warm water. The mixing and resting time of Widjaya (2010) were adopted. The mixture was evenly mixed with flour blend for 5 min to form smooth and homogenous dough. The dough was rested for $30 \mathrm{~min}$, compressed for $1 \mathrm{~min}$ prior feeding into SIMAC Pastamatic 1000 cold extruder (Italy), and extruded via a circular shaped instant noodle die of $2 \mathrm{~mm}$ diameter. The extrudates were steamed as determined, submerged in cold water for $2 \mathrm{~min}$, drained and spread on a tray at room temperature to air dry for $4 \mathrm{~h}$ before oven drying at $55^{\circ} \mathrm{C}$ for $5 \mathrm{~h}$. These were cooled and packaged in low density polyethylene bag.

\section{Determination of proximate composition of noodles}

Moisture, ash, crude fibre, and crude protein contents of pro-vitamin A cassava noodles and commercial noodle (510) were determined followed the procedures of AOAC (2005) of methods 925.09, 930.05, 962.09, and 978.04, respectively. The crude fat contents were analyzed as described by AACC (2000b) using FOSS Soxtec system HT2. The total carbohydrate compositions were determined by deducting other food components from 100 as obtained from Koua et al. (2012) in Equation 2.

Carbohydrate content $=100-($ Moisture + Protein + Ash + Fat) $\%$

\section{Determination of quality attributes of the noodles}

\section{Determination of yellowness}

The yellowness of cassava-African yam bean noodles was investigated by adopting Konica Minolta Chroma metre of model CR-410 as described by Choy (2011).

\section{Determination of hydrogen cyanide}

Hydrogen cyanides of the noodles were investigated by employing the approach of Essers et al. (1993).

\section{Determination of cooking quality}

Cooking yield and cooking loss of noodles were analyzed according to the technique of Chillo et al. (2008).

\section{Determination of textural profiling}

Noodles were prepared for texture profile analysis by employing AACC International Accepted Procedures of 66-50 AACC (2000b) and Oh et al. (1983) using Texture Profile Analyser of model TVT-300XPH.

\section{Model fitting and determination of numerical optimization}

The models fitting was measured via the coefficients of determination $\left(R^{2}\right)$, adjusted $\left(R^{2}\right)$, and analysis of variance (ANOVA). A good fit occurs between experimental data and predicted values of the model when both $R^{2}$ and adjusted $\mathrm{R}^{2}$ were high and close to one along with nonsignificant lack of fit. The numerical optimization of studied processing parameters was performed through the design expert to obtain the best processing parameters. The 
Table 1. Experimental and predicted values of desirable blends.

\begin{tabular}{lcccccc}
\hline Variables & CF (\%) & AYBF (\%) & Beta-carotene $(\boldsymbol{\mu g} / \mathbf{g})$ & Protein (\%) & Fat (\%) & Desirability \\
\hline Predicted values & 70.52 & 29.48 & 6.46 & 6.68 & 0.58 & 0.725 \\
Experimental values & 70.52 & 29.48 & 5.74 & 7.15 & 0.69 & \\
Percentage of agreement & & & 88.85 & 92.96 & 81.03 & \\
Percentage of deviation & & & 11.15 & 7.04 & 18.97 & \\
\hline
\end{tabular}

CF, Pro-vitamin A cassava flour; AYBF, African yam bean flour.

chosen criteria for the responses: hydrogen cyanide, cooking loss, stickiness and chewiness were kept as minimum as their maximum values are not desirable. However, the cooking yield and yellowness were set to maximum to achieve desirable high-quality noodles.

\section{Sensory evaluation of the noodles}

The optimized cassava-African yam bean noodles and commercial noodle were cooked and served to fifty trained females' staff of Cassava Processing Unit of IITA to compare their sensory attributes. The panellists' consents were sought and approved prior the commencement of the evaluation. They were trained on the objectives of the study and the importance of the chosen sensory attributes. A 9-point hedonic ranking was utilized to rank the noodles for colour, flavour, taste, stickiness, chewiness, and overall acceptability of which 9 signifies like tremendously, 1 signifies dislike tremendously and 5 signifies neither like nor dislike.

\section{Statistical analysis}

Samples were investigated repeatedly for three times and data obtained were analyzed statistically. Mean and standard deviation obtained were exposed to one-way ANOVA adopting Statistical Package for Social Sciences (SPSS) (version 20, 2013). Means were compared and separated adopting Duncan's New Multiple Range Test (DNMRT) at 95\% confidence level.

\section{RESULTS AND DISCUSSION}

\section{Response surface methodology of flour blend}

The experimental design produced thirteen flour blend with five central points as reported by Ajibola and Olapade (2019). The protein, $\beta$-carotene and fat contents of these flour blend ranged from 2.31 to $10.52 \%, 3.5$ to $7.60 \mu \mathrm{g} / \mathrm{g}$ and 0.57 to $1.40 \%$, respectively. Meanwhile, the desirable blend, (70.49\% PVAC and $29.51 \%$ AYB) contained $6.69 \%$,
$6.45 \mu \mathrm{g} / \mathrm{g}$ and $0.58 \%$ of protein, $\beta$-carotene and fat contents, respectively. It was observed that the protein content of desirable blend was lower than $7 \%$ which was minimum percentage required for production of highquality noodles (Choy, 2011). Thus, more effort should be made to increase the fortification. The low-fat content of the blend is beneficial as it certifies prolong shelf life of flours (Reebe et al., 2000). The predicted and experimental values of the desirable blend are displayed in Table 1 with 0.725 desirability as depicted. It was observed that the percentage of agreement between these two values was greater than $80 \%$.

\section{Proximate composition of noodles}

The proximate compositions of the noodles are presented in Table 2. It was noted that there were significant $(p \leq 0.05)$ differences in proximate compositions of provitamin A cassava noodles which could be ascribed to the consequence of hydration level and steaming time on the noodles. Likewise, there were significant $(p \leq 0.05)$ differences between pro-vitamin A cassava noodles and commercial noodle based on their proximate compositions. This could be attributed to differences in their ingredients. The moisture contents of noodles ranged from 5.67 to $9.54 \%$ with sample $53: 2$ had the highest moisture, while sample 510 had the lowest. These values compared well with recommended moisture content for airdried noodles of below $14 \%$ as reported by Codex Alimentarius Commission, CAC (2006).

The ash contents of noodles ranged from 1.84 to $3.04 \%$ with sample 53:2 had maximum ash content, whereas sample 510 had the minimum. It was observed that the ash contents of cassava-African yam bean noodles were higher than commercial noodle which implied the presence of more mineral contents than commercial noodle. The result was higher than the findings of Omeire et al. (2014) for composite noodles of values varied from 1.12 to $2.63 \%$. These values were also higher than those stated by Akanbi et al. (2011) with values ranging from 1.3 to $2.3 \%$ for noodles made from breadfruit-starch wheat flour blend. This could be attributed to the difference in their composition. The protein contents of noodles ranged from 
Table 2. Proximate composition of the noodles.

\begin{tabular}{ccccccc}
\hline $\begin{array}{c}\text { Samples codes } \\
\text { HL:ST }\end{array}$ & Moisture (\%) & Ash (\%) & Protein (\%) & Fat (\%) & Crude fibre (\%) & Carbohydrate (\%) \\
\hline $50: 1$ & $8.64 \pm 0.01_{\mathrm{c}}$ & $2.67 \pm 0.00_{\mathrm{b}}$ & $11.55 \pm 0.42_{\mathrm{ab}}$ & $0.88 \pm 0.11_{\mathrm{de}}$ & $2.83 \pm 0.05_{\mathrm{d}}$ & $76.26 \pm 0.54 \mathrm{~b}$ \\
$48.76: 2$ & $8.67 \pm 0.38_{\mathrm{c}}$ & $2.67 \pm 0.47_{\mathrm{b}}$ & $11.36 \pm 0.41_{\mathrm{ab}}$ & $1.07 \pm 0.1_{\mathrm{bc}}$ & $3.20 \pm 0.08_{\mathrm{ab}}$ & $76.23 \pm 1.36_{\mathrm{cd}}$ \\
$56: 3$ & $8.84 \pm 0.16_{\mathrm{bc}}$ & $2.5 \pm 0.24_{\mathrm{bc}}$ & $11.22 \pm 0.46_{\mathrm{b}}$ & $1.09 \pm 0.03_{\mathrm{bc}}$ & $2.18 \pm 0.05_{\mathrm{g}}$ & $76.35 \pm 0.52_{\mathrm{cd}}$ \\
$53: 2$ & $8.68 \pm 0.04_{\mathrm{c}}$ & $2.57 \pm 0.00_{\mathrm{bc}}$ & $10.26 \pm 0.41_{\mathrm{bcd}}$ & $1.08 \pm 0.04_{\mathrm{bc}}$ & $2.84 \pm 0.08_{\mathrm{d}}$ & $77.41 \pm 0.49_{\mathrm{b}}$ \\
$50: 3$ & $8.07 \pm 0.13_{\mathrm{e}}$ & $2.67 \pm 0.00_{\mathrm{b}}$ & $11.70 \pm 0.62_{\mathrm{a}}$ & $1.16 \pm 0.07_{\mathrm{b}}$ & $2.63 \pm 0.06_{\mathrm{e}}$ & $76.4 \pm 0.56_{\mathrm{c}}$ \\
$53: 0.59$ & $9.13 \pm 0.11_{\mathrm{b}}$ & $2.33 \pm 0.00_{\mathrm{ab}}$ & $10.56 \pm 0.83_{\mathrm{bc}}$ & $1.18 \pm 0.08_{\mathrm{b}}$ & $2.49 \pm 0.09_{\mathrm{f}}$ & $76.8 \pm 1.01_{\mathrm{cd}}$ \\
$53: 3.41$ & $9.21 \pm 0.01_{\mathrm{b}}$ & $1.84 \pm 0.23_{\mathrm{d}}$ & $10.15 \pm 0.41_{\mathrm{bcd}}$ & $1.14 \pm 0.02 \mathrm{bc}$ & $2.63 \pm 0.03_{\mathrm{e}}$ & $77.66 \pm 0.18_{\mathrm{c}}$ \\
$56: 1$ & $8.58 \pm 0.04_{\mathrm{cd}}$ & $2.17 \pm 0.23_{\mathrm{c}}$ & $10.08 \pm 0.21_{\mathrm{cd}}$ & $1.09 \pm 0.06_{\mathrm{bc}}$ & $3.41 \pm 0.05_{\mathrm{a}}$ & $78.08 \pm 0.01_{\mathrm{b}}$ \\
$53: 2$ & $8.64 \pm 0.14_{\mathrm{c}}$ & $2.75 \pm 0.35_{\mathrm{b}}$ & $9.98 \pm 0.42_{\mathrm{cd}}$ & $0.93 \pm 1.14_{\mathrm{bcd}}$ & $3.41 \pm 0.05_{\mathrm{a}}$ & $77.7 \pm 0.77_{\mathrm{b}}$ \\
$53: 2$ & $9.54 \pm 0.14_{\mathrm{a}}$ & $2.25 \pm 0.55_{\mathrm{b}}$ & $10.05 \pm 0.62_{\mathrm{cd}}$ & $0.97 \pm 0.21_{\mathrm{bcd}}$ & $3.33 \pm 0.05_{\mathrm{ab}}$ & $77.19 \pm 0.33_{\mathrm{b}}$ \\
$53: 2$ & $8.7 \pm 0.09_{\mathrm{c}}$ & $2.5 \pm 0.00_{\mathrm{bc}}$ & $10.02 \pm 0.21_{\mathrm{cd}}$ & $1.01 \pm 0.04_{\mathrm{bcd}}$ & $3.32 \pm 0.04_{\mathrm{ab}}$ & $77.77 \pm 0.15 \mathrm{~b}$ \\
$53: 2$ & $8.68 \pm 0.09_{\mathrm{c}}$ & $2.5 \pm 0.24_{\mathrm{bc}}$ & $9.95 \pm 0.42_{\mathrm{de}}$ & $0.92 \pm 0.16_{\mathrm{bcd}}$ & $3.1 \pm 0.05_{\mathrm{b}}$ & $77.95 \pm 0.42_{\mathrm{b}}$ \\
$57.24: 2$ & $8.91 \pm 0.03 \mathrm{bc}$ & $2.00 \pm 0.01_{\mathrm{c}}$ & $9.25 \pm 0.21_{\mathrm{f}}$ & $0.88 \pm 0.21_{\mathrm{de}}$ & $3.44 \pm 0.04 \mathrm{a}$ & $78.92 \pm 0.44 \mathrm{a}$ \\
510 & $5.67 \pm 0.05_{\mathrm{f}}$ & $3.04 \pm 0.03_{\mathrm{a}}$ & $9.89 \pm 0.02_{\mathrm{de}}$ & $4.95 \pm 0.1 \mathrm{a}_{\mathrm{a}}$ & $0.49 \pm 0.03_{\mathrm{h}}$ & $76.46 \pm 0.23 \mathrm{c}$ \\
\hline
\end{tabular}

$\mathrm{HL}$, Hydration level (\%); ST; steaming time ( $\mathrm{min})$; 510, commercial noodle. Values are means of three replicates \pm standard deviation. Average values of dissimilar subscript within a column are significantly $\left({ }^{\star} \mathrm{P}<0.05\right)$ different.

9.25 to $11.70 \%$ with sample $50: 3$ having the maximum protein content, while sample $57.24: 2$ had the minimum. These values were in the range of values obtained from Omeire et al. (2014) for composite noodles of values varied from 8.96 to $26.47 \%$. It was observed that as hydration level was increasing, the protein contents of cassava-African yam bean noodles were diminishing. However, the steaming duration did not have a significant influence on protein compositions of the noodles.

The fat contents of noodles varied from 0.88 to $4.95 \%$ with sample 510 having the maximum fat content, while samples 57.24:2 and 50:1 had the minimum. These values were lower than those reported by Jayasena et al. (2008) of values ranged from 8.09 to $14.44 \%$ for lupinfortified instant noodles. Crude fibre contents of noodles ranged from 0.49 to $3.44 \%$ with sample $57.24: 2$ having the maximum crude fibre, while sample 510 had the minimum. The carbohydrate contents of noodles ranged from 76.23 to $78.92 \%$ with sample $57.24: 2$ having the highest carbohydrate content, while sample 53:0.59 had the least. The carbohydrate composition obtained in this study were higher than those obtained from Vijayakumar et al. (2010) of values varied from 48 to $67.5 \%$ for noodles made from millet flour blend.

\section{Verification of fitted models}

The ANOVA results, estimated coefficients of secondorder response models, coefficient of determination, $\mathrm{R}^{2}$, adequate precision, adjusted $\mathrm{R}^{2}$, $\mathrm{F}$-value, and lack of fits (LoF) for all responses of noodles are displayed on Table
3. It was observed that the fitting models were adequate because all the responses had both high $\mathrm{R}^{2}$ and adjusted $\mathrm{R}^{2}$, and non-significant lack of fits. The central composite design of the quality attributes of cassava noodles was presented in Table 4. The results indicated that the predicted values were not significantly different from experimental values of the responses. Thus, this could indicate that the experimental values might be anticipated with high accuracy.

\section{Quality attributes of noodles}

\section{Color}

The color measurement of food is being utilized as a secondary indicator for other quality features (Pathare et al., 2013) and is recognized as the major component of noodle marketability ( $\mathrm{Li}$ et al., 2012). Therefore, color determination is very important in the consumer's perception of noodle quality. The yellow colour of provitamin A cassava-based food is due to its carotenoids content (Atwijukire et al., 2019). Hence, yellowness $\left(b^{*}\right)$ is chosen as one of the quality attributes of pro-vitamin A cassava noodles. The values of yellowness of PVAC noodles obtained in this study ranged from 15.91 to 18.56 . These values compared with the ranges reported by Widjaya (2010) with values 11.0 to 21.8 for instant noodles. High $R^{2}$, of 0.824 , adjusted $R^{2}$ of 0.698 , and a non-significant lack of fit were obtained for yellowness which suggested that the model could predict experimental data. It was observed that the linear, quadratic and 
Table 3. ANOVA results for responses of cassava-AYB noodles.

\begin{tabular}{|c|c|c|c|c|c|c|}
\hline Coefficients & $\begin{array}{c}\text { Hydrogen } \\
\text { cyanide }(\mathrm{mg} / \mathbf{k g})\end{array}$ & $\begin{array}{c}\text { Cooking yield } \\
(\%)\end{array}$ & $\begin{array}{c}\text { Cooking loss } \\
(\%)\end{array}$ & Chewiness (g) & Stickiness (g) & Yellowness \\
\hline$A_{0}$ & 1.13 & 1152.6 & 9.22 & $7.38 \mathrm{E}+005$ & 2327.82 & 6.13 \\
\hline$A$ & 1.27E-05 & 232.29 & 0.45 & 11589.2 & 959.18 & 0.37 \\
\hline$A^{2}$ & 0.05 & 158.66 & 0.29 & $2.43 \mathrm{E}+05$ & 490.12 & 2.25 \\
\hline$B^{2}$ & 0.21 & 573.95 & 0.93 & 13183.91 & 74.33 & 3.18 \\
\hline $\mathrm{B}^{3}$ & 0.18 & - & 1.33 & 57321.8 & - & \\
\hline $\mathrm{R}^{2}(\%)$ & 89.03 & 85.03 & 95.21 & 99.52 & 85.82 & 82.40 \\
\hline Adeq. Prec. & 9.16 & 7.24 & 15.18 & 40.62 & 9.76 & 6.228 \\
\hline Adj. $R^{2}(\%)$ & 73.66 & 74.34 & 88.49 & 98.84 & 75.69 & 69.82 \\
\hline F-Value & 5.79 & 7.95 & 14.18 & 147.02 & 8.47 & 6.55 \\
\hline
\end{tabular}

$\mathrm{A}_{0}$, Regression coefficient of constant; $\mathrm{A}$, linear regression constant of hydration level; $\mathrm{B}$, linear regression constant for steaming time; $\mathrm{A}^{2}$, quadratic regression coefficient for level; $B^{2}$ Quadratic regression coefficient for steaming time, $A B$, Interactive regression the coefficient for hydration level and steaming time; $R^{2}$, coefficient of determination; LoF, Lack of fit; Adeq. Prec., adequate precision; Adj. $R^{2}$, adjusted $R^{2}$; NS, non-significant.

Table 4. Central composite design with experimental and predicted values of quality attributes of cassava noodles.

\begin{tabular}{|c|c|c|c|c|c|c|c|c|c|c|c|c|c|c|}
\hline \multicolumn{3}{|c|}{ Actual values and coded values } & \multicolumn{6}{|c|}{ Experimental values } & \multicolumn{6}{|c|}{ Predicted values } \\
\hline Run & $\begin{array}{l}\mathrm{HL} \\
(\%)\end{array}$ & $\begin{array}{c}\mathrm{ST} \\
(\mathrm{min})\end{array}$ & $\begin{array}{c}\mathrm{HCN} \\
(\mathrm{mg} / \\
\mathrm{kg})\end{array}$ & $\begin{array}{l}\text { CY } \\
(\%)\end{array}$ & $\begin{array}{l}\mathrm{CL} \\
(\%)\end{array}$ & $\begin{array}{c}\text { Chewiness } \\
\text { (g) }\end{array}$ & $\begin{array}{l}\text { Stickiness } \\
\text { (g) }\end{array}$ & Yellowness & $\begin{array}{c}\mathrm{HCN} \\
(\mathrm{mg} / \mathrm{k} \\
\mathrm{g})\end{array}$ & $\begin{array}{l}\text { CY } \\
(\%)\end{array}$ & $\begin{array}{l}C L \\
(\%)\end{array}$ & $\begin{array}{c}\text { Chewiness } \\
\text { (g) }\end{array}$ & $\begin{array}{l}\text { Stickiness } \\
\text { (g) }\end{array}$ & Yellowness \\
\hline 1 & $50(-1)$ & $1(-1)$ & 0.6 & 185.74 & 7.68 & 305.5 & 18.5 & 18.56 & 0.5 & 190.75 & 7.57 & 321.94 & 21.59 & 18.18 \\
\hline 2 & $48.76(1.414)$ & $2(0)$ & 1.01 & 189.3 & 8.76 & 261.5 & 26.5 & 17.29 & 1.11 & 186 & 8.87 & 245.06 & 20.83 & 17.7 \\
\hline 3 & $56(1)$ & $3(1)$ & 1.31 & 209.93 & 7.17 & 254.5 & 28 & 18.17 & 1.21 & 203.58 & 7.06 & 270.94 & 34.29 & 17.95 \\
\hline 4 & $53(0)$ & $2(0)$ & 0.89 & 197.57 & 8.89 & 775 & 42.5 & 16.19 & 0.8 & 203.17 & 8.61 & 793.13 & 52.56 & 16.35 \\
\hline 5 & $50(-1)$ & $3(1)$ & 1.8 & 177.84 & 8.58 & 543.5 & 30 & 17.94 & 1.7 & 177.1 & 8.47 & 559.94 & 38.39 & 17.44 \\
\hline 6 & $53(0)$ & $0.59(-1.414)$ & 0.9 & 186.95 & 7.58 & 691.5 & 53.5 & 17.35 & 0.8 & 183.55 & 7.69 & 675.06 & 52.56 & 17.56 \\
\hline 7 & $53(0)$ & $3.41(1.414)$ & 1.2 & 181.73 & 7.96 & 753.5 & 48 & 17.45 & 1.3 & 186.46 & 8.07 & 737.06 & 49.56 & 17.84 \\
\hline 8 & $56(1)$ & $1(-1)$ & 0.9 & 186.42 & 10.8 & 1082 & 68.5 & 16.91 & 1 & 185.82 & 10.7 & 1098.44 & 69.48 & 16.81 \\
\hline 9 & $53(0)$ & $2(0)$ & 0.73 & 201.95 & 8.8 & 791 & 52 & 16.68 & 0.83 & 203.17 & 8.61 & 793.13 & 52.6 & 16.35 \\
\hline
\end{tabular}


Table 4. Contd.

\begin{tabular}{|c|c|c|c|c|c|c|c|c|c|c|c|c|c|c|}
\hline 10 & $53(0)$ & $2(0)$ & 0.7 & 208.96 & 8.17 & 800.35 & 56 & 15.91 & 0.8 & 203.17 & 8.61 & 793.13 & 52.6 & 16.35 \\
\hline 11 & $53(0)$ & $2(0)$ & 0.98 & 205 & 8.42 & 777.8 & 55 & 16.36 & 0.8 & 203.17 & 8.61 & 793.13 & 52.6 & 16.35 \\
\hline 12 & $53(0)$ & $2(0)$ & 0.7 & 202.39 & 8.77 & 821.5 & 57.5 & 16.61 & 0.8 & 203.17 & 8.61 & 793.13 & 52.6 & 16.35 \\
\hline 13 & $57.24(-1.414)$ & $2(0)$ & 0.73 & 196.61 & 9.06 & 610.5 & 54.5 & 17.08 & 0.8 & 201.24 & 9.17 & 594.06 & 51.3 & 17.18 \\
\hline
\end{tabular}

$\mathrm{HL}$, Hydration level; ST, steaming time; $\mathrm{HCN}$, hydrogen cyanide; $\mathrm{CY}$, cooking yield; CL, cooking loss.

interaction terms between hydration level and steaming duration were significant for yellowness, yielding the model equation as displayed. The model equation showed that hydration level had a higher effect on the yellowness of noodles due to its higher absolute value of coefficient compared to steaming time.

Yellowness $=16.35-0.21 \mathrm{~A}+0.098 \mathrm{~B}+$ $0.57 A^{2}+0.68 B^{2}+0.47 A B$

Where $\mathrm{A}=$ Linear regression constant of hydration level, $\mathrm{B}=$ linear regression constant of steaming time, $A^{2}=$ Quadratic regression coefficient of hydration level, $\mathrm{B}^{2}=$ Quadratic regression coefficient of steaming time, $A B=$ Interactive regression coefficient of hydration level and steaming time.

\section{Hydrogen cyanide}

The hydrogen cyanide values obtained in this study fell within the tolerable limit of $10 \mathrm{mg} \mathrm{HCN}$ eqv $/ \mathrm{kg}$ of cassava flour as endorsed by Food and Agriculture Organisation of United Nations and World Health Organisation, FAO/WHO (2013) and African Organisation for Standardisation, ARSO (2012). The results also indicated that both experimental values and predicted values were similar resulting in both high $\mathrm{R}^{2}(0.893)$ and adjusted $R^{2}(0.737)$, and a non-significant lack of fit. This generated a model equation that showed that both hydration level and steaming time had significant effect on hydrogen cyanide. It was noted that steaming time had higher significant influence on hydrogen cyanide compared to hydration level due to its higher coefficient. According to Asegbeloyin and Onyimonyi (2007) and CAC/RCP (2013), the existence of cyanogenic glucosides constitutes main restriction to the utilization of cassava as human diet. Hence, hydrogen cyanide determination is very essential in evaluating the quality attributes of cassava-based foods.

Hydrogen cyanide $=0.80+3.99-0.03 \mathrm{~A}+0.7 \mathrm{~B}+$ $0.083 A^{2}+0.17 B^{2}-0.2 A B-0.051 A^{3}-0.3 B^{3}$

\section{Cooking qualities}

The experimental values of cooking yield and cooking loss ranged from 177.84 to $209.93 \%$, and 7.17 to $10.8 \%$, respectively. These values were comparable to predicted values as shown. There were high $R^{2}$ of 0.85 and 0.952 , adjusted $R^{2}$ of 0.743 and 0.885 , and non-significant lack of fits for cooking yield and cooking loss, respectively. The effect of hydration level and steaming time on these cooking qualities resulted in the model equations as displayed on Equations 5 and 6 . It was indicated that the role of hydration level was more significant on cooking yield than steaming time. This was due to its higher value of its coefficient: 5.39 versus 1.03. Meanwhile, the effect of steaming time was substantial on cooking loss of noodles compared to hydration level.

Cooking yield $=203.17+5.39 \mathrm{~A}+1.03 \mathrm{~B}-$

$4.78 A^{2}-9.08 B^{2}+7.85 A B$

Cooking loss $=8.61+0.75 \mathrm{~A}-1.5 \mathrm{~B}+0.2 \mathrm{~A}^{2}-$

$0.37 B^{2}-1.13 A B-0.32 A^{3}+0.82 B^{3}$

\section{Texture profile analysis}

Chewiness and stickiness of the noodles are essential textural properties considered in the quality attribute of noodles. Their experimental values ranged from 254 to $1082 \mathrm{~g}$ and 18.5 to 68.5 $\mathrm{g}$ for chewiness and stickiness, respectively. These textural properties generated the model equations as displayed. It was observed that the hydration level had more significant influenced on the chewiness and stickiness than steaming time. The higher the hydration level in noodle, the higher would be the stickiness. Meanwhile, the steaming time was inversely proportional to the stickiness 
Table 5. Validation of experimental and predicted results of the noodles.

\begin{tabular}{|c|c|c|c|c|c|c|c|c|c|}
\hline Variables & $\begin{array}{c}\text { Hydration } \\
\text { level (\%) }\end{array}$ & $\begin{array}{c}\text { Steaming } \\
\text { time (s) }\end{array}$ & $\begin{array}{c}\text { Hydrogen cyanide } \\
(\mathrm{mg} / \mathrm{kg})\end{array}$ & $\begin{array}{l}\text { Cooking } \\
\text { yield (\%) }\end{array}$ & $\begin{array}{l}\text { Cooking } \\
\text { loss (\%) }\end{array}$ & $\begin{array}{c}\text { Chewiness } \\
(\mathrm{g})\end{array}$ & $\begin{array}{c}\text { Stickiness } \\
(\mathrm{g})\end{array}$ & Yellowness & Desirability \\
\hline Predicted values & 50 & 1 & 0.5 & 190.75 & 7.57 & 321.94 & $(-) 21.59$ & 18.18 & 0.801 \\
\hline Validated values & 50 & 1 & 0.62 & 185.74 & 7.68 & 305.5 & $(-) 18.5$ & 18.56 & \\
\hline Percentage of agreement & & & 80.65 & 97.37 & 98.57 & 94.89 & 85.69 & 97.95 & \\
\hline Percentage of deviation & & & 19.35 & 2.63 & 1.43 & 5.11 & 14.31 & 2.05 & \\
\hline Predicted values & 56 & 3 & 1.21 & 203.58 & 7.06 & 270.94 & $(-) 34.29$ & 17.95 & 0.766 \\
\hline Validated values & 56 & 3 & 1.31 & 209.93 & 7.17 & 254.5 & $(-) 28$ & 18.17 & \\
\hline Percentage of agreement & & & 92.37 & 96.98 & 98.47 & 93.93 & 81.66 & 98.79 & \\
\hline Percentage of deviation & & & 7.63 & 3.02 & 1.53 & 6.07 & 18.34 & 1.21 & \\
\hline
\end{tabular}

Table 6. Sensory evaluation of cassava-African yam bean and commercial noodles.

\begin{tabular}{cccccccc}
\hline Noodles codes & Appearance & Taste & Colour & Stickiness & Chewiness & Aroma & Overall acceptability \\
\hline $50: 1$ & $6.93 \pm 1.10_{\mathrm{b}}$ & $6.6 \pm 1.55_{\mathrm{b}}$ & $6.4 \pm 1.29_{\mathrm{b}}$ & $6.73 \pm 1.39_{\mathrm{ab}}$ & $6.73 \pm 1.54 \mathrm{ab}$ & $6.87 \pm 0.99_{\mathrm{ab}}$ & $7.07 \pm 1.03_{\mathrm{b}}$ \\
$56: 3$ & $5.53 \pm 1.96_{\mathrm{c}}$ & $5.67 \pm 1.8_{\mathrm{b}}$ & $6.73 \pm 1.03_{\mathrm{b}}$ & $5.93 \pm 1.58_{\mathrm{b}}$ & $6.13 \pm 1.46_{\mathrm{b}}$ & $6.22 \pm 1.87_{\mathrm{b}}$ & $6.07 \pm 1.1_{\mathrm{c}}$ \\
510 & $8.07 \pm 0.88_{\mathrm{a}}$ & $8.13 \pm 0.74_{\mathrm{a}}$ & $8.13 \pm 0.99_{\mathrm{a}}$ & $7.4 \pm 1.06_{\mathrm{a}}$ & $7.67 \pm 0.38_{\mathrm{a}}$ & $7.33 \pm 0.38_{\mathrm{a}}$ & $8.27 \pm 0.8_{\mathrm{a}}$ \\
\hline
\end{tabular}

510 , Commercial noodle. Values are means of three replicates \pm standard deviation. Average values of dissimilar subscript within a column are significantly ( $\mathrm{P}<0.05)$ different.

. This indicated that prolong steaming time exposed the noodles to sufficient gelatinisation of noodles strands that could result in a reduction of stickiness.

Chewiness $=793.13+120.36 \mathrm{~A}-316.67 \mathrm{~B}-186.78 \mathrm{~A}^{2}$. $43.53 B^{2}-266.37 A B+1.52 A^{3}+169.30 B^{3}$

Stickiness $=52.6+10.95 \mathrm{~A}-4.6 \mathrm{~B}-13 \mathrm{AB}-$ $8.39 A^{2}-3.27 B^{2}$

\section{Numerical optimization and verification of optimum conditions}

The two desirable solutions were obtained to produce acceptable noodles with desirability 0.801 and 0.766 for samples $50: 1$ and $56: 3$, respectively. These were validated in the laboratory and the validation results of the responses with their predicted values were displayed on Table 5. It was observed that the percentage of agreement of predicted values with experimental values for all the responses were greater than $80 \%$ for the two desirable noodles.

\section{Sensory evaluation}

The sensory evaluation scores of two optimized experimental noodles (50:1 and 56:3) and commercial noodle (510) were presented on Table 6 . These scores ranged from 5.53 to 8.27 with the commercial noodle having the highest score. Sample 50:1 rated next to commercial noodle in overall acceptability with its least value of 6.4 for color and highest value of 7.07 for overall acceptability. There were no significant $(p \geq 0.05)$ differences in experimental noodles based on their taste, color, stickiness, chewiness, and aroma. 
However, there were significant differences in appearance and overall acceptability of both experimental and commercial noodles.

\section{Conclusion}

Optimization offers opportunities for scientific research on new product development. Response Surface Methodology was applied to optimize the nutritional value of blend and processing parameters of noodles based on its chosen quality attributes. The best processing parameters of quality attributes of cassava-African yam bean noodles were obtained with RSM. The established models presented a good fit with the examined data at $95 \%$ confidence level. The noodles processed with the optimized processing parameters showed enhanced quality attributes. Furthermore, the sensory evaluation of the optimized noodles showed acceptable scores in all the sensory attributes. Cassava-African yam bean noodles of acceptable nutritional, cooking and sensory qualities were developed from the mixtures of PVAC and AYB flours.

\section{ACKNOWLEDGEMENTS}

The authors acknowledged the support of the staff of Cassava Processing Unit and GRC of IITA, Ibadan for provision of pro-vitamin A cassava roots and AYB seeds, respectively. Authors also appreciated the kind gesture received from the staff of Crop Utilization Laboratory of IITA during laboratory analyses.

\section{REFERENCES}

AACC (2000a). Approved methods of the American Association of Cereal Chemists Method $30-25,105^{\text {th }}$ Ed. St. Paul, MN: AACC International., 1018p.

AACC (2000b). Approved methods of the American Association of Cereal Chemists Methods 08-01, 46-30, 55-40, 66-50, 76-13, and 76e31, $10^{\text {th }}$ Ed. St Paul, MN: AACC International.

Abidin A. Z., Devi C. \& Adeline (2013). "Development of Wet Noodles Based on Cassava Flour.", J. Eng. Technol. Sci., 45(1): 97-111. https://doi: 10.5614/j.eng.technol.sci.2013.45.1.7.

Adewale B. D. \& Odoh N. C. (2013). A review on genetic resources, diversity and agronomy of African yam bean [(Sphenostylis stenocarpa (Hochst. ExA. Rich.) Harms]): A potential future food crop. Sustainable Agriculture Research., 2(1): 32-43. Accessed on $10^{\text {th }}$ May, 2020 from http://dx.doi.org/10.5539/sar.v2n1p32http://dx.doi.org/10.5539/sar.v2 n1p32.

Ahmed S. \& Hasan M. M. (2014). Legumes: An overview. J. of Pharm. Pharm. Sci. 2(1):34-38.

Ajayi A. O. (2011). Sustainable dietary supplements: An analytical study of African yam bean (Sphenostylis sternocarpa) and corn (Zea Maiz)., Eur. J. Exp. Biol. 1(4):189-201. Accessed on 13 ${ }^{\text {th }}$ May, 2020 from www.pelagiaresearchlibrary.comwww.pelagiaresearchlibrary.com. Ajibola G. O. \& Olapade A. A. (2019). Physico-chemical and functionalproperties of cassava and African yam bean flour blends. Appl. Trop. Agric. 24(1):200-207.

Akanbi T. O., Nazamid S., Adebowale A. A., Farooq A. A. \& Olaoye A. O.
(2011). Breadfruit starch-wheat flour noodles: Preparation, proximate compositions and culinary properties. Int. Food Res. J. 18(4):12831287.

Akinoso, R., Igbeka, J. C., Olayanju, T. M. A. \& Bankole, L. K. (2006). Process optimisation of oil expression from sesame seed (Sesamum indicum Linn.). Agri. Eng. Int. 8:1-7.

Aniedu C. \& Omodamiro R. M. (2012). Use of newly bred $\beta$-Carotene cassava in production of value-added products: Implication for food security in Nigeria. Global J. Sci. Frontier Res. Agric. Vet. Sci. 12(10):1.

AOAC (2005). Official Methods of Analysis, 18 ${ }^{\text {th }}$ Ed. Association of Official Analytical Chemists, Washington, D.C: AOAC International.

ARSO (2012). Composite flour specification. African organisation for standardisation. ARS 841 https://archive.org/details/ars.841https://archive.org/details/ars.841. Accessed on August 20, 2019.

Asegbeloyin J. N. \& Onyimonyi A. E. (2007). Effect of different processing methods on the residual cyanide of 'Gari'. Pak. J. Nutr. 6:163-166. https://doi.org/10.3923/pjn.2007.163.16610.3923/pjn.2007.163.166.

Atwijukire E., Hawumba J. F., Baguma Y., Wembabazi E., Esuma W., Kawuki R. S. \& Nuwamanya E. (2019). Starch quality traits of improved provitamin A cassava (Manihot esculenta Crantz). Heliyon., 5:1-18. Accessed from https://doi.org/10.1016/j.heliyon.2019.e012152405$8440 /$.

CAC (2006). Codex Alimentarius Commission: Codex standard for instant noodles, Publication No. CODEX STAN 249-2006.

CAC/RCP 73 (2013). Codex Alimentarius Commission: Code of practice for the reduction of hydrocyanic acid $(\mathrm{HCN})$ in cassava and cassava products. Available at: http://www.fao.org/input/download/standards/13605/CXP_073e.pdf.

Carvalho L. M. J., Oliveira A. R. G., Godoy R. L. O., Pacheco S., Nutti M. R., De Carvalho J. L. V., Pereira E. J. \& Fukuda W. G. (2012). Retention of total carotenoid and $\beta$-carotene in yellow sweet cassava (Manihot esculenta Crantz) after domestic cooking. Food Nutr. Res. 56:15788-15797. Accessed on $13^{\text {th }}$ May, 2020, from http://doi.10.3402/fnr.v56i0.15788.

Chillo S., Laverse J., Falcone P. M., Protopapa A. \& Del Nobile M. A. (2008). Influence of the addition of buckwheat flour and durum wheat bran on spaghetti quality. J. Cer. Sci. 47(2): 144-152. https://doi: 10.1016/j.jcs.2007.03.004.

Choy A. L. (2011). Enhancing the quality of instant noodles. The impact of low protein wheat flour, ingredients and processing conditions. A PhD thesis submitted to School of Applied Sciences, Science, Engineering and Health Portfolio RMIT University, Malaysia. $\mathrm{xx}+184 \mathrm{pp}$.

Dickson R. A., Annan K., Fleischer T. C., Amponsah I. K., Nsiah K. \& Oteng J. A. (2012). Phytochemical investigations and nutritive potential of eight selected plants from Ghana. J. Pharm. Nutr. Sci. 2:172-177. http://dx.doi.org/10.6000/1927-5951.2012.02.02.9.

Essers A. J. A., Bosveld M., Van der Grift R. M. \& Voragen A. G. J. (1993). Studies on the quantification of specific cyanogens in cassava products and introduction of a new chromogen. J. Sci. Food Agric. 63: 287-296. http://doi.10.1002/jsfa.274063030510.1002/jsfa.2740630305.

Eyidemir E. \& Hayta M. (2009). The effect of apricot kernel flour incorporation physicochemical and sensory properties of noodles. Afr. J. Biotechnol. 8(1):85-90.

FAO (2012). The State of food insecurity in the world 2012. Economic growth is necessary but not sufficient to accelerate reduction of hunger and malnutrition. Rome: FAO http://www.fao.org/docrep/016/i3027e/i3027e.pdf

FAO (2017). Statistical database. Cassava, production quantity (tons) for all countries. FAOSTAT, http://www.factfish.com/statistic/cassava\%2C\%20production\%20qua ntity.

FAONHO (2013). Proposed draft maximum levels for hydrocyanic acid in cassava and cassava products. Joint $\mathrm{FAO} / \mathrm{WHO}$ food standards programme Codex committee on contaminants in foods. CX/CF.13/7/10. Rome: Codex Alimentarius Commission, Italy.

Jayasena V., Leung P., Nasar-Abbas S. M., Palta J. \& Berger J. (2008). 
Development and quality evaluation of lupin-fortified instant noodles. In J. A. Palta and J. B. Berger (eds). Lupin for health and wealth. Proceedings of 12th international lupin conference. 14-18 Sept. 2008. Fremantle, Western Australia. International Lupin Association, Canterbury, New Zealand.

Koua G. Y. A., Megnanou R., Kouassi A., Séverin Kra K. A. S., N'zue B., Bi D. R. T., Tian Bi D. R., Akpa E. E. \& Niamké S. L. (2012). Biochemical characterization of new varieties of yellow coloured pulp cassava flours from Côte d'Ivoire. J. Appl. Biosci. 53:3760-3772.

Li P., Huang C., Yang M. \& Wang C. (2012). Textural and sensory properties of salted noodles containing purple yam flour. Food Res. Int. 47(2): 223-228. https://doi:10.1016/j.foodres.2011.06.035.

Nwabueze T. U. \& Anoruoh A. G. (2009). Clustering acceptance and hedonic responses to cassava noodles extruded from cassava mosaic disease-resistant varieties. Afr. J. Food Sci. 3(2):334-339. https://www.academicjournals.org/ajfs.

Nwosu J. N., Ahaotu I., Ayazie C., Udeoozor L. O. \& Ahaotu N. N., (2011). The proximate and functional properties of African yam bean (Sphenostylis stenocarpa) seeds as affected by processing. Niger. Food J. 29(2):39-48.

Oh N. H., Seib P. A., Deyoe C. W. \& Ward A. B. (1983). Noodles. I. Measuring the textural characteristics of cooked noodles. Cereal Chem. 60(6):433-438.

Ohimain E. I. (2014). The prospects and challenges of composite flour for bread production in Nigeria. Global J. Hum. Soc. Sci. Interdisc. 14(3):43-52.

Oladunmoye, O. O., Aworh, O. C., Maziya-Dixon, B., Erukainure, O. L. and\& Elemo, G. N. (2014). Chemical and functional properties of cassava starch, durum wheat semolina flour, and their blends. Food Sci. Nutr. 2. 2:132-138.

Oluwamukomi M. O., Oluwalana I. B. \& Akinbowale O. F. (2011). Physicochemical and sensory properties of wheat-cassava composite biscuit enriched with soy flour. Afr. J. Food Sci. 5(2):50-56. https://www.academicjournals.org/ajfshttps://www.academicjournals. org/ajfs

Omeire G. C., Umeji O. F. \& Obasi N. E. (2014). Acceptability of noodles produced from blends of wheat, acha and soybean composite flours. Niger. Food J. 32(1):31-37.

Pathare P. B., Opara U. L. \& Al Said F. A. (2013). Colour measurement and analysis in fresh and processed foods: A review. Food Bioproc. Tech. 6:36-60. https://doi.10.1007/s11947-012-0867-9.
Reebe, S., Gonzalez, V. N. \& Rengifo, J. (2000). Research on trace elements in common beans. Food Nutr. Bull. 21:387-391.

Sowmyapriya S., Kalarani M. K., Jeyakumar P., Kennedy Z. J., Velmurugan M. \& Arumugam T. (2017). Assessment of biochemical changes during postharvest physiological deterioration in cassava tubers. Int. J. Pure Appl. Biosci. 5(2):732-739. https://doi.org/10.18782/2320-7051.2514

Vijayakumar, P. T., Mohankumar, J. B. \& Srinivasan, T. (2010). Quality evaluation of noodles from millet flour blend incorporated composite flour. J. Sci. \& Ind. Res. 69:48-54.

Widjaya C. (2010). The impact of ingredients formulation and processing parameters on colour and texture of instant noodles. PhD. Thesis. School of Applied Sciences. RMIT University. $x x+184 p p$.

WINA (2011). Expanding market. World Instant Noodles Association. http://instantnoodles.org/ noodles/expanding-market.html. Retrieved July $11^{\text {th }}, 2011$.

WINA (2016). Global demand for instant noodles. World Instant Noodles Association. https://instantnoodles.org/en/noodles/market.html. Accessed November 16th, 2017.

Zvinavashe E., Elbersen H. W., Slingerland M., Kolijn S. \& Sanders, J. P. M. (2011). Cassava for food and energy: exploring potential benefits of processing of cassava into cassava flour and bioenergy at farmstead and community levels in rural Mozambique. Int. J. Pure Appl. Biosci. 5(2):151-164. https://doi.org/10.1002/bbb.272. 